\title{
Non-US Citizen
}

National Cancer Institute

\section{Source}

National Cancer Institute. Non-US Citizen. NCI Thesaurus. Code C90518.

A person who is not a legal citizen of the United States. 